\title{
Editorial
}

\section{Private equity funds: Champions of governance and disclosure?}

\author{
International Journal of Disclosure and Governance (2007) 4, 217-220. \\ doi:10.1057/palgrave.jdg.2050068
}

I am writing this Editorial only days after panic and massive losses in stock markets around the world driven by the collapse of many of the components that have defined financial markets in the first decade of the 21 st century: the idea that 'securitisation' can transform sub-prime mortgages and what used to be called 'junk' bonds into AAA-rated securities; that mathematical models and other if-you-have-to-ask-thenyou-won't-understand financial alchemies can essentially eliminate risk; and at the bottom of all of this, that private equity and hedge funds exploiting these tools and using capital provided by rich, ultra-sophisticated investors rather than 'widows and orphans' can take over even the largest of publicly traded firms (Chrysler, Hilton Hotels, HCA, Hertz, etc) and by doing so generate extraordinary returns (Kohlberg Kravis Roberts \& Co's Millennium Fund generated a net internal rate of return of 41 per cent up to 2006 - and today, the firm, which proposed to spend $\$ 24$ billion to acquire First Data and $\$ 37$ billion for TXU, is facing increasing difficulty in getting banks to lend it the money to complete these deals) with equally incredible fees (at least three hedge fund managers took home over $\$ 1$ billion each in compensation in 2007).

That might make it an odd time to be talking about such funds in anything other than a disparaging way, as vehicles of greed and excess getting their well-deserved comeuppance. Yet, precisely because many are forecasting the end of the boom in private equity funds and the precedent setting takeovers that they have made in recent years, it is important to take a more balanced view of what these funds have accomplished. Whatever the shortcomings and arrogance that these funds demonstrated over the last few years, the fact is that the rise of private equity capital is a point of inflection in the evolution of financial markets, offering a third way, along with trading on public stock exchanges and issuing debt, for businesses to finance their operations and for entrepreneurs to raise fund to market their innovations. And as with those two other sources of capital, private equity funding has its advantages and disadvantages that must be considered by shrewd investors and corporate treasurers, rather than being condemned out of hand. Especially in times of panic, the temptation must be resisted to throw the baby out with the bathwater.

In July I had the good fortune of listening to the plenary speech at the International Conference of the Institute of Internal Auditors in Amsterdam delivered by the famed governance expert, board director, adviser to the World Bank and United Nations, and Justice of the Supreme Court of South Africa, Mr Mervyn E. King. ${ }^{1}$ Part of his comments addressed private equity funds and built on the themes of his 4 April op-ed in the Financial Times. In that article, unfortunately entitled 'Voodoo notions' of private equity must be debunked', Mr King stated that while many disparage the public lack of disclosure and transparency of private equity and hedge funds and call for their regulation or even their outright ban, these critics fail to take into account the benefits arising from the relationship between the funds 
and the firms that they acquire. A takeover by private equity capital essentially transforms a closely regulated public corporation with widely dispersed ownership structure into a tightly bound owner-managed enterprise, which fundamentally changes the governance conditions within the firm.

And while that speech made only a month ago already seems to be from another time and age when everyone wanted to be a fund manager, nonetheless, Mr King's points warrant careful analysis, especially when he backed up his argument with evidence from the United Kingdom (where an astonishing 20 per cent of all private sector employees now work for a firm owned by private equity) that private equity fund-owned firms are leaders both in profitability, and perhaps more unexpectedly, also in job creation. Thus, at least on the evidence he provides, there is something to be said for private equity funds as drivers of corporate governance.

As Mr King stated in his FT editorial:

'Management schemes in private equity transactions are structured so that there is an alignment between the institutional investor and management. Managers do not share only in the upside, as in the traditional share option scheme. They have to participate in the upside and the downside. A "voodoo notion" is that there is less transparency for investors in private equityowned companies. The reality is that the institutional investor has unrestricted access to management. Discussion between the two is absolutely transparent and the investors urge managers from time to time to change course strategically. Managers in turn regularly share issues with the investors. Managers and investors are not restricted by insider trading regulations. The institutional owner of shares in a listed company can only discuss with executives issues that are in the public domain. Consequently, there is greater disclosure to the providers of capital in a company owned by a private equity fund than in a publicly listed company. Management and ownership are not split. Then there are the notions of a lack of compliance and reporting. Publicly owned companies listed on exchanges are driven by short-term issues. They have to report every three months in some jurisdictions, in others every six months. Management is measured on short-term issues and compliance-driven. The management of a private equity fund company is measured and rewarded on long-term strategic issues and the achievement of a hurdle rate of return many points above the long-term cost of capital and borrowing. In private equity, there is a freedom from an almost mindless compliance with regulations. The reporting to investors is quick and absolutely transparent. Another issue is decision-making. In a private equity context, it is much quicker than in a listed company. The decision is made after a direct communication between the owner-investors and management.'

In his IIA speech, Mr King reiterated these points, emphasising that in his extensive experience as a company director, he felt that he had much more freedom to talk directly to executives and outside stakeholders in his private equity fund-owned firms than in publicly traded firms subject to tight regulations. These include not only the insider trading restrictions he complains about in the FT article, but also in the USA, regulation FD, that requires that any communication from the firm has to be available to everyone or to no one, and so essentially prevents targeted private communication with key stakeholders.

And he was equally adamant that contrary to popular perception that private equity funds are only interested in 'flipping and stripping' companies, private equity capital is potentially more patient and more willing to take a longer term view of the firm given that it is more than a marginal owner of the firm and not answerable to analysts with their incessant demands for quarterly earning's 'guidance'. 
To put it another way, private equity fund firms are explicitly not looking to reduce risk by taking only a small position in any one firm in order to form a diversified portfolio, but instead take a large position in a firm precisely because that forces them to actively manage the firm and make sure that it improves its performance. By this view, private equity funds are an antidote to the 'buy and sell with a click' investor who has no incentive to pay attention to any one firm in his portfolio, let alone care about how well or how poorly it performs, how well it is governed, or even, how socially responsible a firm it is.

Of courses, it is an open question whether Mr King or anyone else will say these things today. While markets are rebounding on the day that I write, they did the same a month ago before last week's dramatic falls. And there seems to be little doubt that there is more pain to come in asset valuations, and more painful reassessments of the fundamental assumptions that went into the way in which private equity funds operated and raised their capital. In particular, Mr King does not mention the increasing convergence over the last few years between the long-term oriented private equity funds and hedge funds with their blink-of-aneye quantitative models that have been particularly badly hit over the last week. (Goldman Sachs signature Global Alpha hedge fund which was up 40 per cent in 2006 is reputedly down 30 per cent so far this year - and at the time of writing, Goldman is issuing denials that the fund will shortly be liquidated.)

And yet, there is equally little doubt in my mind that there is something very important and new in the way in which private equity capital affects corporate governance, and even corporate disclosure, if that term is broadly interpreted to mean communications between owners and managers, rather than simply mandated disclosures to shareholders of a publicly held firm. Time will reveal whether Mr King's views are prescient or hubristic, but the points he makes about the effect on governance of the rise of the private equity economy
- and indeed, whether one could go as far as to say that the former is essentially the rationale for the latter - are too important to ignore.

Perhaps precisely because we in the International Journal of Disclosure \& Governance community have been too slow to make that link, it is noticeable that this journal has had little to say about private equity funds to date. That changes in this issue with an excellent article by Peter Yeoh on the regulatory approach in the UK towards private equity and hedge funds, which, written before last week's events, discussed the 'moral panic' that their collapse might bring about. But this article is still considering such funds as a target for regulation and better governance, rather than being themselves a driver of best practices in governance. I would like to invite our readers to think about and write up their thoughts on the role that private equity funds play in corporate governance and share their views, as Mr King did, with letters to the editor and papers that expand on their views.

And as we think about the pros and cons of private equity funds in this regard, think too about the impending emergence of funds that may have an even bigger impact on financial markets - and about whom it is much harder to be sanguine as far as governance and disclosure are concerned: the so-called 'Sovereign Wealth Funds' of China, Russia and oil-rich nations that already possess some $\$ 2.5$ trillion in assets - double the total assets of all hedge funds - that they are increasingly looking to invest in publicly traded western firms.

Already there is growing concern in Europe over the strategic and political risks such investments pose, since for these state-owned funds national interest is, after all, paramount. This makes it hard to know how to assess a transaction such as the recent Russian SWF stake in the Airbus Consortium. And given the history of intellectual property violations in China, would a purchase of a western high-tech or pharmaceutical company by its $\$ 300$ billion Public Investment Fund be for the purposes of increasing the firm's performance and taking it 
public at a profit, as a conventional private equity fund would do, or to gain access to the firm's patents? As German Chancellor Angela Merkel stated recently: 'With those sovereign funds we now have a new and completely unknown elements in circulation. One cannot simply react as if these are completely normal funds of privately pooled capital'. There is certainly a need for more discussion in the journal of the governance practices of these SWFs (and to be fair, of the internal workings of western hedge funds too, and particularly their relationship with the bond rating agencies that made securitisation feasible), but it is hard to see where to start with such research. It is even harder to imagine a future Mervyn King writing that Sovereign Wealth Funds are actually champions of good corporate governance in the firms that they have taken a stake in.

As the recent threats made by high Chinese officials to use their US Treasury bond holdings as an economic weapon in retaliation for American pressure to devalue the Chinese currency indicates, Sovereign Wealth Funds can operate in ways that make private equity funds seem benign by contrast. And the lack of internal transparency that private equity funds manifest pale in comparison to that of SWFs owned by President Putin's Russia or by Middle Eastern potentates.

At least the wealthy private investors in private equity funds care only about making money, which gives them a reason to want to make sure that their investments are well managed and profitable with strong corporate governance practices, as opposed to making investments as a means of enhancing national security or punishing enemies. The day may yet come when we fondly recall the famous saying from Wall Street - the movie, not the address - that 'Greed is Good'. That may well be the saving grace of the battered and bruised private equity industry.

\section{Michael Alles \\ Issue Editor}

\author{
Note \\ 1 Not to be confused with Mervyn A. King, \\ Governor of the Bank of England.
}

